\title{
Four new Agapantbia (Epoptes) Gistel, 1857 (Coleoptera, Cerambycidae) from the West Siberia, Kazakhstan, Azerbaijan and Iran
}

\section{Четыре новых Agapantbia (Epoptes) Gistel, 1857 (Coleoptera, Cerambycidae) из Западной Сибири, Казахстана, Азербайджана и Ирана}

\author{
M.L. Danilevsky

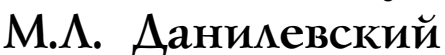

A.N. Severtsov Institute of Ecology and Evolution, Russian Academy of Sciences, Leninskij Prosp. 33, Moscow 119071 Russia. E-mail: danilevskyml@rambler.ru; danilevsky@cerambycidae.net.

Институт проблем экологии и эволюции им. А.Н. Северцова РАН, Ленинский пр. 33, Москва, 119071 Россия.

Key words: new subspecies, taxonomy, Cerambycidae, Lamiinae, Agapanthia (Epoptes), Azerbaijan, Kazakhstan, Iran, Russia.

Ключевые слова: новые подвиды, таксономия, Cerambycidae, Lamiinae, Agapanthia (Epoptes), Азербайджан, Казахстан, Иран, Россия.

Abstract. Agapanthia (Epoptes) dahli (Richter, 1820) now includes 15 subspecies [Lazarev, 2013a, b; Lazarev et al., 2016]. Three new subspecies are described: A. (E.) d. kuleshovi ssp. n. (Russia, Tomsk environs), A. (E.) d. lepsyensis ssp. n. (Kazakhstan, Lepsy river valley), A. (E.) d. iliensis ssp. n. (Kazakhstan, Ili river basin), as well as one new subspecies of $A$. (E.) lederi Ganglbauer, 1884: A. (E.) l. hodeki ssp. n. (Iran, Gilan, Elburs Mts. and Azerbaijan, Talysh).

Резюме. Agapanthia (Epoptes) dahli (Richter, 1820) сейчас включает 15 подвидов [Lazarev, 2013a; 2013b; Lazarev et al., 2016]. Описаны три новых подвида: $A$. (E.) d. kuleshovi ssp.n. (Россия, окрестности Томска), A. (E.) d. lepsyensis ssp.n. (Казахстан, долина реки Лепсы), $A$. (E.) d. iliensis ssp.n. (Казахстан, бассейн реки Или), как и новый подвид $A$. (E.) lederi Ganglbauer, 1884: $A$. (E.) $l$. hodeki ssp.n. (Иран, Гилян, горы Эльбурс и Азербайджан, Талыш).

The subspecies structure of many Agapanthia Audinet-Serville, 1835 species is very complicated. New collecting efforts in poorly studied regions show the existence of new subspecies. Four of them are described bellow.

Abbreviations of collections: DK - collection of D. Kuleshov (Tomsk, Russia), KH - collection of K. Hodek (Brno, Czech Republic), LS - collection of L. Skořepa - (Peč, Czech Republic), MD - collection of M.L. Danilevsky (Moscow), MM - collection of M. Mař́k (Prague, Czech Republic).

\section{Agapanthia (Epoptes) dahli kuleshovi ssp. n. Figs 1-2.}

Material. Holotype - $0^{7}$, Russia, Tomskaya Obl., Belousovo env., 56 $18^{\prime} 13^{\prime \prime} \mathrm{N}, 85^{\circ} 11^{\prime} 53^{\prime \prime} \mathrm{E}, 14.7 .2013$ D. Kuleshov leg. (MD). Paratypes - 940 $0^{7}$, 61우, same locality, 1.07.2003, 1.07.2005, 30.06-24.07.2008, 2.07.2009, 10.08.2010，4-18.06.2011，9-18.06.2012，26.06-4.08.2013 D. Kuleshov leg. (DK and MD); 10', 3우 - Tomskaya Obl.,

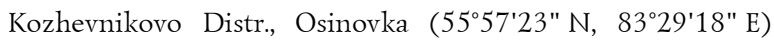
env., 25.06.1993, 25.07.1993, V. Tyagelsky (DK).

Description. The new subspecies is geographically close to A. (E.) calculensis Lazarev, 2013 from north-east Kazakhstan, but morphologically strongly different: body much bigger; antennae very long, reaching elytral apices in males by $6^{\text {th }}$ or $7^{\text {th }}$ antennal joints, in female - by $8^{\text {th }}$ or $9^{\text {th }}$ antennal joints, but very rare about as long as elytra - surpassing elytral apices by $11^{\text {th }}$ joint only; $3^{\text {rd }}$ antennal joints with dense setae tufts, though short; $4^{\text {th }}$ antennal joint without tufts; dorsal elytral pubescence very dense, orange-yellow, often nearly totally hiding elytral surface, often nearly uniform, with poorly arranged setae patches; black erect elytral setae near elytral bases relatively short, disappearing near elytral middle; grey humeral elytral stripe absent; the nominative subspecies has usually long setae tufts of $3^{\text {rd }}$ antennal joints, strongly spotted elytra with numerous distinct setae patches and glabrous areas in between; erect elytral setae longer and wider distributed along elytral surface; body length in males: 13.0-21.4 mm, width: $3.3-6.0 \mathrm{~mm}$, body length in females: $17.7-22.5 \mathrm{~mm}$, width: $4.6-6.5 \mathrm{~mm}$.

Distribution. Two populations are known in the south of Tomskaya Oblast of Russia in the environs of Belousovo $\left(56^{\circ} 18^{\prime} 13^{\prime \prime} \mathrm{N}, 85^{\circ} 11^{\prime} 53^{\prime \prime} \mathrm{E}\right)$ and in the environs of Osinovka

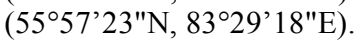

Biology. Imagoes are active from the beginning of June to the beginning of August. All beetles were observed on Heracleum.

\section{Agapanthia (Epoptes) dahli lepsyensis ssp. n. Figs 3-4.}

Material. Holotype - $\sigma^{7}$, Kazakhstan, Lepsy river, $7 \mathrm{~km}$ NE Koilyk, 4541'36.22" N, 80¹7'58.94" E, 3.6.2016, K. Hodek leg. (MD). Paratypes - 3우 with same label (KH and MD); 1ㅇ - Kazakhstan, Lepsinsk environs, 10.06.2001, O. Gorbunov leg. (MD).

Description. The new subspecies is close to A. (E.) dahli alexandris Pic, 1901 (described from Kirgizsky mountain ridge and known eastwards to the slopes of Zailiysky Alatau) because of long and dense setae tufts of $3^{\text {rd }}$ antennal joints, 

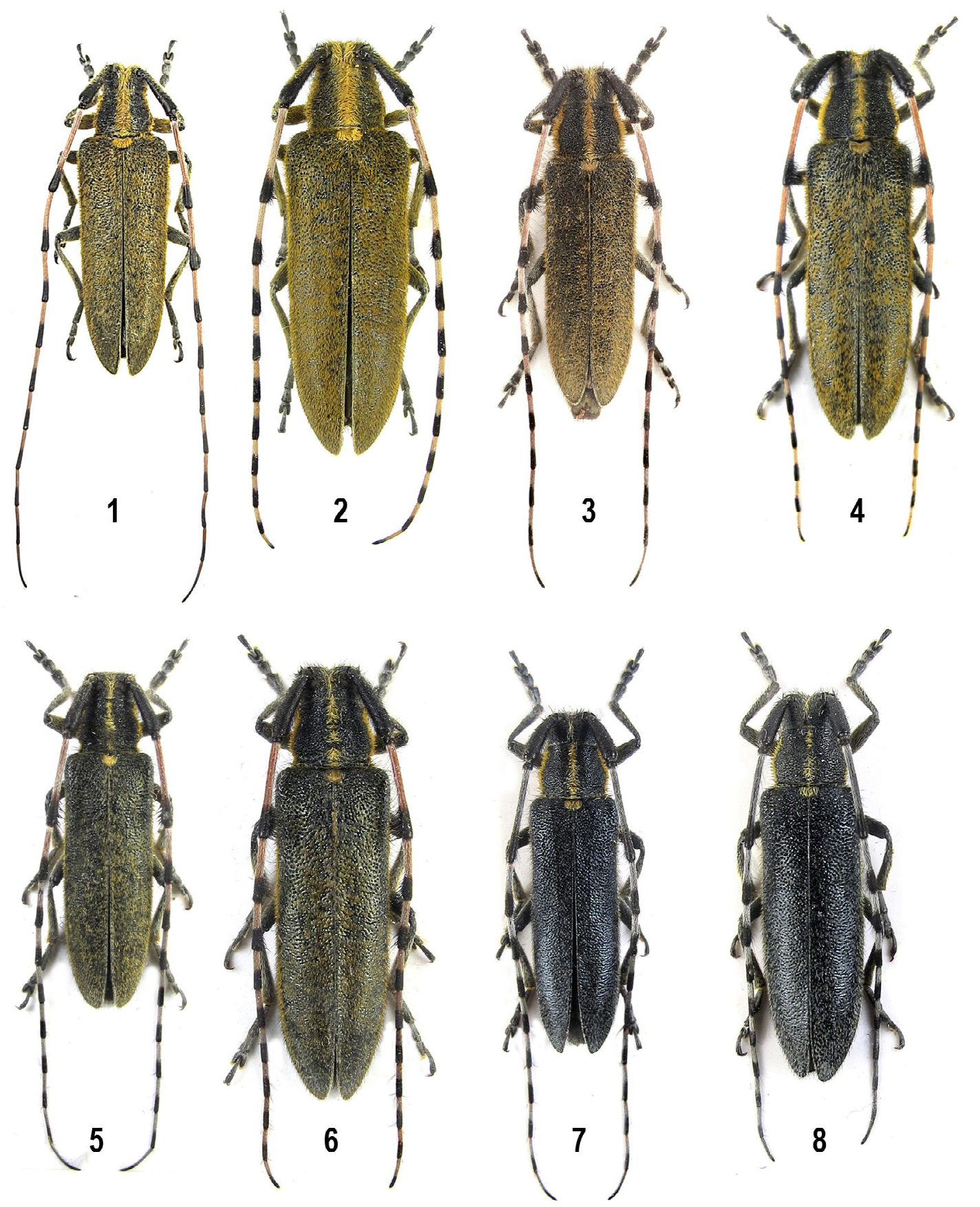

Figs 1-8. Agapanthia spp.: 1 - A. (Epoptes) dabli kuleshovi ssp.n., male, holotype; 2 - A. (E.) dabli kuleshovi ssp.n., female, paratype; 2 - A. (E.) dabli lepsyensis ssp.n., male, holotype (photo by K. Hodek); 3 - A. (E.) dabli lepsyensis ssp.n., female, paratype; $5-$ A. (E.) dabli iliensis ssp.n., male, holotype, $6-$ A. (E.) dahli iliensis ssp.n., female, paratype; $7-$ A. (E.) lederi bodeki ssp.n., male, holotype (photo by K. Hodek); 8 - A. (E.) lederi hodeki ssp.n., female, paratype.

Pис. 1-8. Agapanthia spp.: 1 - A. (Epoptes) dabli kuleshovi ssp.n., самец, голотип; 2 - A. (E.) dabli kuleshovi ssp.n., самка, паратип; 2 - A. (Е.) dabli lepsyensis ssp.n., самец, голотип (фотография слелана К. Холеком); 3 - A. (Е.) dahli lepsyensis ssp.n., самка, паратип; 5 - A. (E.) dabli iliensis ssp.n., самец, голотип; 6 - A. (E.) dabli iliensis ssp.n., самка, паратип; 7 - A. (E.) lederi bodeki ssp.n., самец, голотип (фотография сделана К. Ходеком); 8 - А. (Е.) lederi hodeki ssp.n., самка, паратип. 
bright and dense yellow-orange elytral pubescence, but grey humeral stripes absent; elytra pubescence distinctly denser, more even, with less pronounced setae patches, setae tufts of $4^{\text {th }}$ antennal joints poorly developed (usually distinct in A. d. alexandris); black erect elytral setae very long near elytral bases, disappearing near elytral middle; body length in male: $16.5 \mathrm{~mm}$, width: $4.4 \mathrm{~mm}$, body length in females: 15.3 $17.6 \mathrm{~mm}$, width: $3.8-4.7 \mathrm{~mm}$.

Distribution. Kazakhstan, Lepsy river valley: $7 \mathrm{~km}$ NE Koilyk, 4541'36.22" N, 80¹7'58.94" E and near Lepsinsk.

Biology. Imagoes are active at the beginning of June. Beetles were observed on Malva.

\section{Agapanthia (Epoptes) dahli iliensis ssp. n. Figs 5-6.}

Material. Holotype - $\sigma^{7}$, Kazakhstan, Almatinskaya Oblast, at the road south of Lake Sorbulak $\left(43^{\circ} 33^{\prime} 57.65^{\prime \prime} \mathrm{N}\right.$, 76³6'24.93" E), 670 m, 7.06.2016, K. Hodek leg. (MD)

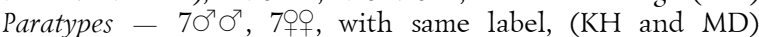
$10^{\top}$ - from same locality, 7.06.2016, M. Mařik leg. (MM).

Description. The taxon is geographically close to A. (E.) dahli alexandris Pic, 1901 from neighbor mountains of Zailiysky Alatau, but easily differs because of poorly developed elytral pubescence; elytra looks relatively dark; small sparse setae patches separated with strongly shining cuticula areas; antennae also darker, than usually in $A$. dah$l i$ - red-brown; antennal setae tufts strongly developed, long and dense, usually distinct up to $5^{\text {th }}$ joint; black erect elytral setae very long near elytral bases, disappearing near elytral middle; grey humeral elytral stripe absent; body length in males: $14.0-19.7 \mathrm{~mm}$, width: $3.5-4.7 \mathrm{~mm}$, body length in females: $15.1-19.7 \mathrm{~mm}$, width: $3.7-5.0 \mathrm{~mm}$.

Distribution. Kazakhstan, Almatinskaya Oblast, plane northwards Zailiysky Alatau; one population known near the road southwards Sorbulak lake $\left(43^{\circ} 33^{\prime} 57.65^{\prime \prime} \mathrm{N}\right.$, 76³6'24.93" E).

Biology. Imagoes are active at the beginning of June. Beetles were observed on Malva.

\section{Agapanthia (Epoptes) lederi hodeki ssp. n. Figs 7-8.}

Material. Holotype - $\sigma^{7}$, «Iran, p. Gilan, Rostamabad, $12 \mathrm{~km} \mathrm{W,} 1550 \mathrm{~m}, 6.06 .2017,36^{\circ} 55^{\prime}, 4^{\circ} 23$ ', K. Hodek leg.» (MD). Paratypes - 200 $0^{7}$, 699 with same label (KH and MD); $10^{\top}, 2$ क +9 - «Iran, NW, prov. Gilan, Salaneh Sar, $20 \mathrm{~km}$ W Rostamabad, 4.06.2015, Lgt. Skořepa» (LS); $10^{7}-$ «Kasp. Meer-Geb. / Talysch / 1897 Korb» (MD); 10 - Talysh, 10.05.1988, Voronin (MD); 107, 2 O9 - Talysh, 17.07.1981, S.Nikireev (MD); 1 우 - Lerik, 7.05.1983, S. Nikireev (MD); 1 우 - Talysh, Avrora, 28.05.1979, M. Danilevsky leg. (MD).

Description. The taxon is close to different Caucasian mountain populations, which were identified as A. subchalybaea Reitter, 1898 (from Black Sea slopes to many localities in Central Caucasus) or A. subnigra Pic, 1890 (from Georgia), but probably better must be classified as subspecies of $A$. lederi Ganglbauer, 1884.
Body black with metallic luster; eyes big, but lower eye lobes a little shorter then genae; antennae black, certain antennal joints can be narrowly reddish basally; white antennal rings poorly pronounced occupying about a half or more of each joint; $1^{\text {st }}$ and $2^{\text {nd }}$ antennal joints combined about as long as $4^{\text {th }}$ joint; $3^{\text {rd }}$ joint much longer; in males $7^{\text {th }}$ antennal joint far surpassing elytral apices, in females $9^{\text {th }}$ joint hardly reaching elytral apices; prothorax about 1.2 times wider then long in males or 1.3 times in females; angulated laterally behind middle; much narrower anteriorly than posteriorly; pronotum without pale recumbent pubescence, but with narrow central longitudinal line; erect sparse black pronotal setae moderately long; elytrae in males about 4.3 times longer then basal width, in females - about 3.9 times; with more or less narrow rounded apices; elytral punctation very small and dense; sparse recumbent pubescence very short, indistinct; grayish pale humeral stripe usually indistinct, but in population from lowland (Avrora environs) pale elytral pubescence denser and grey humeral stripe visible; erect black elytral setae moderately long in anterior elytral half; male pygidium deeply emarginated, last male sternite feebly emarginated, nearly truncated; last abdominal tergite in females nearly truncated, sternite - emarginated; body length in males: 13.3-16.8 mm; width: $3.4-4.2 \mathrm{~mm}$; body length in females: $12.2-16.9 \mathrm{~mm}$; width: $3.0-4.3 \mathrm{~mm}$.

Distribution. Elburs mountain ridge and Talysh mountains with foothills; Iran, Gilan, about $12 \mathrm{~km}$ north-westwards Rostamabad (36 $\left.55^{\prime} \mathrm{N}, 4^{\circ} 23^{\prime} \mathrm{E}\right)$; Azerbaijan, Talysh (several localities including Lerik and Aurora).

Biology. Imago active from May to June. The beetles were observed on local Sambucus similar to Central European $S$. ebulus. It is interesting to note, I collected many specimens of typical A. lederi Gang., on about same food plant in North Caucasus near Krasnodar.

Etymology. The taxon is dedicated to Karel Hodek, who collected the holotype and most part of the type series.

\section{Acknowledgements}

I am very grateful to Dmitry Kuleshov (Tomsk) and Karel Hodek (Brno) for loan of the specimens for study. My sincere thanks to Karel Hodek for 2 photos of specimens.

\section{References}

Lazarev M. A. 2013a. A new subspecies of Agapanthia dahli (C.F.W. Richter, 1820) from North-East Kazakhstan (Coleoptera: Cerambycidae) // Studies and reports of District Museum Prague-East. Taxonomical Series. Vol.9. No.1. P.127-131.

Lazarev M. A. 2013b. Two new subspecies of Agapanthia dahli (Richter, 1821) from Dagestan and Armenia (Coleoptera, Cerambycidae) // Humanity space. International almanac. Vol.2. No.3. P.443-448.

Lazarev M. A., Plewa R., Jaworski T. 2016. Two new subspecies of Agapanthia (Epoptes) dahli (C.F.W. Richter, 1820) from South-East Azerbaijan and North Iran // Humanity Space. International Almanac. Vol.5. No.2. P.230-238. 